
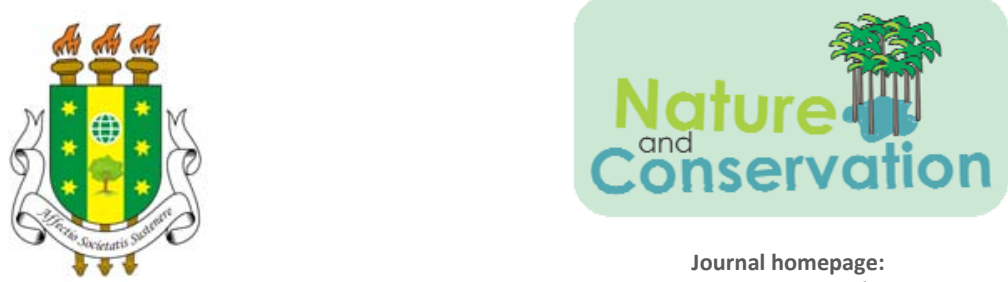

Journal homepage:

www.arvore.org.br/seer

\section{PARQUE NACIONAL DOS CAMPOS GERAIS (PR) E TURISMO: UM OLHAR ATRAVÉS DA COMUNIDADE LOCAL}

\section{RESUMO}

Este trabalho possui como objeto de estudo o Parque Nacional dos Campos Gerais (PNCG), localizado no centro-leste do Estado do Paraná e tem como objetivo geral uma análise da percepção dos moradores do Passo do Pupo, comunidade de entorno do Parque, sobre esta unidade de conservação. A metodologia se deu através de uma pesquisa qualitativa, com levantamento bibliográfico, visitas in loco e aplicação de vinte e um questionários com questões abertas e fechadas realizadas em vinte e uma moradias dispostas na comunidade. Buscou-se identificar com este estudo o interesse pelo Turismo destes moradores, no sentido de analisar o potencial de oferta como fator de desenvolvimento e sustentabilidade local. Como resultado, observou-se que a maior parte dos entrevistados mostra-se favorável ao PNCG e à participação na atividade turística.

PALAVRAS-CHAVE: Turismo; Comunidade Local; Unidade de Conservação.

\section{PARQUE NACIONAL DOS CAMPOS GERAIS (PR) AND TOURISM: A LOOK THROUGH THE LOCAL COMMUNITY}

\section{ABSTRACT}

This paper has as main goal a study about Campos Gerais National Park (PR), located at center-east of the Paraná State with the general objective an analysis of the perception of the residents of Passo do Pupo, because this community is around that conservation unit. The methodology was through qualitative research with literature review, visits in loco and application of twenty-one questionnaires with open and closed questions arranged in the community. It had been tried to identify with this study interest in Tourism these residents in order to analyze the potential offer as a factor of development and local sustainability. As a result, it was observed that most of the residents agreed to PNCG creation and desire to participate in tourism activities.

KEYWORDS: Tourism; Local Community; Conservation Unit.
Nature and Conservation,

Aquidabã, v.6, n.1, Nov, Dez 2012, Jan, Fev, Mar, Abr 2013.

\section{ISSN 2318-2881}

\section{SECTION: Articles}

TOPIC: Conservação da Natureza

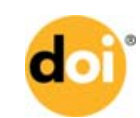

DOI: 10.6008/ESS2318-2881.2013.001.0002

\section{Leandro Baptista}

Universidade Estadual de Ponta Grossa, Brasil http://lattes.cnpq.br/4353198473576287 leandro.baptista@live.com

\section{Jasmine Cardozo Moreira}

Universidade Estadual de Ponta Grossa, Brasi http://lattes.cnpq.br/4244565636923524 jasminecardozo@gmail.com

Received: $11 / 01 / 2013$

Approved: 08/03/2013

Reviewed anonymously in the process of blind peer.

\section{Referencing this:}

BAPTISTA, L.; MOREIRA, J. C.. Parque Nacional dos Campos Gerais (PR) e turismo: um olhar através da comunidade local. Nature and Conservation, Aquidabã, v.6, n.1, p.22-45, 2013. DOI: 


\section{INTRODUÇÃO}

O avanço da degradação ambiental em áreas naturais, como estações ecológicas, reservas biológicas e parques nacionais, pode ser entendido por razões que vinculam-se principalmente ao capitalismo. Sujeitos ávidos por aumentar seus lucros, não medem esforços para alterar características naturais das paisagens visando ampliar sua área produtiva e também devido ao desconhecimento da fundamental necessidade de manter um equilíbrio dinâmico com os recursos disponíveis.

Ao diagnosticar este cenário verifica-se que o homem parece não se dar conta que faz parte da natureza, sendo o principal sujeito prejudicado com a diminuição da qualidade e da diversidade global. A natureza e o universo social, cultural e econômico formam uma rede de relações, desta forma, os seres passam de objetos para sujeitos, sempre interligados, onde as ações antes vistas como isoladas, passam a afetar toda uma cadeia de possibilidades e oportunidades.

Assim, entende-se que um dos caminhos que podem ser traçados para que ocorra esta conscientização acerca do ambiente natural, se dá através do turismo em conjunto com a educação ambiental. Para tanto, percebe-se que este binômio pode ainda favorecer as comunidades de entorno de Unidades de Conservação (UC's), com oportunidades para a geração de emprego e renda à população local, cumprindo, desta maneira, com os objetivos propostos pela sustentabilidade.

Além da Educação Ambiental, outras oportunidades são lançadas ao planejar ambientes naturais que contenham em sua formação comunidades locais, sejam estas tradicionais ou não, capazes de sofrer influência com a implantação de Unidades de Conservação no seu entorno. Estas oportunidades podem ser verificadas através da comercialização de produtos artesanais, a participação de agentes em meios personalizados em interpretação ambiental, como trabalhadores nos serviços oferecidos aos visitantes entre outros.

Diante deste contexto, o Parque Nacional dos Campos Gerais - PR (PNCG) mostra-se com potencial favorável para a aplicação destas ferramentas, fazendo-se cumprir os objetivos descritos em seu Decreto de criação e diversificando as opções para o fluxo de demanda existente. Assim, os fatores bióticos, abióticos, sociais e culturais podem constituir o amálgama de interesses de visitação, ampliando sua relevância econômica e ambiental.

Portanto, procurou-se com este estudo, verificar junto aos moradores do vilarejo do Passo do Pupo, comunidade localizada entre interseção da área norte e sul do Parque Nacional dos Campos Gerais, a percepção local sobre o PNCG e seus atrativos e a atividade turística.

Como principais resultados, observou-se que a comunidade têm uma relação de descontentamento por não terem sido procurados por órgãos do poder público para discutir as oportunidades geradas pelo PNCG. Ainda assim, 80\% dos entrevistados mostraram-se favoráveis 
para trabalhar com o Turismo, apontando como principal deficiência do local a via de acesso ao Parque.

Ciente de que os moradores destas comunidades receberão os impactos negativos e positivos que a atividade turística produz, cabe aos responsáveis pela gestão do Parque Nacional administrar tais efeitos gerados com objetivos de ampliar os benefícios potenciais nas esferas social, econômico, cultural e ambiental. Contudo, ações paliativas, com intuito de ambientar estes moradores acerca do PNCG devem ser executas em curto prazo, afim de reverter a atual impressão sobre esta Unidade de Conservação (UC).

\section{REVISÃO TEÓRICA}

\section{Turismo: Atividade Multidisciplinar e Complexa}

A atividade turística se caracteriza através de um caráter multidisciplinar, e por apoiar-se nesta base, permite os mais diferentes enfoques de trabalhos sobre matrizes sociais, econômicas, culturais, ambientais, jurídicas, entre outras. Devido a este amálgama de interpretações, muitos são os autores que procuram dar inteligibilidade e compreender a atividade, podendo ser citados Fúster (1991), Moesch (2002) e Beni (2004).

Entretanto, apesar da complexidade existente para a compreensão do Turismo, a forma mais comum de enxergar a atividade ainda remete para seus balanços imediatos verificados na esfera econômica. Cabe, porém ressaltar os demais efeitos que a atividade produz, não menos importantes que seus impactos financeiros. Pode-se transbordar esta perspectiva através de Fúster (1991, p.26-27), onde:

Turismo es, por un lado, conjunto de turistas, que cada vez son más numerosos; por el outro, son los fenómenos y relaciones que esta masa produce a consecuencia de sus viajes. Turismo es todo el equipo receptor de hoteles, agencias de viajes, transportes, espetáculos, guías-intérpretes, etcétera, que el núcleo debe habilitar para atender a las corrientes turísticas que lo invaden $-\mathrm{y}$ que no promoveria si no lãs recibieste. Turismo es las organizaciones privadas o públicas que surgen para fomentar la infraestructura y la expansión del núcleo; las campañas de propaganda que hay que planear, ejecutar y difundir (...). También es Turismo los efectos negativos o positivos que se producen en las poblaciones receptoras - económicos, sociales, religiosos, etc.

Nesta definição, percebe-se que a questão do Turismo tem como preocupação a análise das transformações que geradas com o contato do visitante junto ao núcleo receptor no decorrer da viagem e a infraestrutura turística necessária para que o destino atenda às expectativas dos turistas. Pode-se desta maneira, verificar os desdobramentos incorporados à atividade sem que a questão econômica ocupe o maior destaque entre estes.

O conceito adotado pelo órgão máximo do Turismo (UNWTO), passou de um caráter conservador para uma versão mais abrangente, que considera desta vez, os segmentos de 
negócios e os visitantes que permanecem por um período inferior ha 24 horas na destinação, categorizados como excursionistas, sendo:

Tourism is a social, cultural and economic phenomenon witch entails the movement of people to countries or places outside their usual environment for personal or business/professional purposes. These people are called visitors (which may be either tourists or excursionists; residents or non-residents) and tourism has to do with their activities, some of which imply tourism expenditure. (UNWTO, 2008).

Esta posição reitera a preocupação da atividade em organizar-se e acompanhar as evoluções naturais que alteraram os paradigmas do Turismo no século XXI, adaptando-se assim, às novas formas de viagens e oferecendo condições para que estas possam ser desenvolvidas com segurança e qualidade para preservar os benefícios desencadeados pelo setor.

Torna-se perceptível neste ponto, que o Turismo é uma atividade que oferece a prestação de serviços aos seus consumidores, participando assim, do setor terciário da economia. Desta forma, se faz necessário entender o fenômeno sob o ponto de vista social, já que este deve representar a coluna central para seu planejamento. Concorda-se com Horodyski (2006, p.28) ao comentar que: "tão importante quanto as questões econômicas destacadas, são os benefícios socioculturais resultantes (...) desde que haja um planejamento da atividade turística".

A atividade é portanto um fenômeno no que se refere às mudanças que traz consigo em aspectos ambientais, econômicos, sociais e culturais. Devido essa complexidade, certamente ela poderá alterar o modo de vida dos moradores de uma localidade visitada, contribuindo para seu crescimento ou atravancando se não for bem planejada. Refletindo sobre estas especificidades, Beni (2004, p.37) descreve o Turismo como,

Um elaborado e complexo processo de decisão sobre o que visitar, onde, como e a que preço. Nesse processo intervêm inúmeros fatores de realização pessoal e social, de natureza motivacional, econômica, cultural, ecológica e científica que ditam a escolha dos destinos, a permanência, os meios de transporte e o alojamento, bem como o objetivo da viagem em si para a fruição tanto material como subjetiva dos conteúdos de sonhos, desejos, de imaginação projetiva, de enriquecimento existencial histórico-humanístico, profissional, e de expansão de negócios.

Este conceito engloba outros aspectos relacionados à atividade, incluindo fatores motivacionais, respeito ao processo de escolha por segmento e por tipo de turista e também inclui fatores de desenvolvimento humano. Assim, é possível notar a abrangência e a multidisciplinaridade presentes no Turismo, bem como os elementos preponderantes à sua concretização, pois sabe-se que o Turismo tem implicações em vários setores da economia e representa uma fonte de entrada de divisas e geração de empregos diretos e indiretos.

Desta forma, percebe-se que além das características inerentes do Turismo, existem subdivisões internas de sua estrutura, que estão diretamente relacionadas com sua demanda potencial. Estas subdivisões são chamadas de segmentações de mercado e representam as 
razões que levam ao deslocamento dos turistas. Portanto, reconhecer com qual tipo de segmento se está planejando amplia as possibilidades de sucesso e satisfação dos visitantes.

Assim, abordam-se no próximo tópico algumas reflexões acerca do Turismo em áreas naturais, para melhor compreensão sobre o fenômeno estudado no presente artigo.

\section{Turismo em Ambientes Naturais}

Consciente da necessidade de ter um balizamento motivacional como referência para a gestão e planejamento de destinações, o Ministério do Turismo - Mtur (BRASIL, 2010, p.11) posiciona-se em favor da segmentação de mercados que possam corresponder às expectativas dos visitantes ao comentar que,

A permanente busca de novos produtos turísticos pelos consumidores tem levado a mudanças nas estratégias de planejamento, gestão e promoção do turismo, privilegiando a oferta segmentada de produtos turísticos. Este novo comportamento de compra tem exigido cada vez mais a criação e a oferta de produtos direcionados para demandas especificas, visando oferecer diferentes experiências para os visitantes.

De acordo com Moreira (2011), esta vertente enquadra o Brasil na tendência global de estimular o Turismo especializado. Isto se explica devido à grande dificuldade em desenvolver em apenas uma região diferentes opções de viagens, incorporando a estrutura necessária para que se desenvolva com qualidade. Assim, é comum no mercado internacional, lugares ou até mesmo países com uma vocação turística única, sejam de sol e mar; por singularidades culturais ou um grande centro de negócios, por exemplo.

Buscando compreender as segmentações do Turismo, procura-se estabelecer o critério incentivador para que o visitante tenha interesse em conhecer, conforme observa-se no quadro abaixo:

Quadro 1: Segmentos do turismo em áreas naturais suas principais motivações

\begin{tabular}{|l|l|}
\hline \multicolumn{1}{|c|}{ Segmento } & \multicolumn{1}{|c|}{ Característica elou motivação } \\
\hline Agroturismo & $\begin{array}{l}\text { Deslocamento de pessoas a espaços rurais para vivenciar e participar de atividades } \\
\text { agropastoris }\end{array}$ \\
\hline Aventura & Busca por experiências que tragam emoção e "adrenalina" \\
\hline Birdwatching & Observação e captura de imagens de pássaros em seu ambiente natural \\
\hline Ecológico & $\begin{array}{l}\text { Pessoas que apreciam o contato com a natureza, respirar ar puro, fotografar paisagens, } \\
\text { etc. }\end{array}$ \\
\hline Ecoturismo & $\begin{array}{l}\text { Realizar atividades junto à natureza, que envolvam aspectos de educação e interpretação } \\
\text { ambiental. Enfoque principal na natureza }\end{array}$ \\
\hline Geoturismo & $\begin{array}{l}\text { Interesse em conhecer melhor sobre os aspectos geológicos e geomorfológicos de um } \\
\text { determinado local }\end{array}$ \\
\hline Lazer & Fugir da rotina e conhecer novos lugares \\
\hline Paisagístico & $\begin{array}{l}\text { Principal produto é a paisagem e aspectos cênicos da natureza, compreendendo } \\
\text { características geográficas, ecológicas e mesológicas }\end{array}$ \\
\hline Rural & Descanso, contato com tradições do campo \\
\hline
\end{tabular}

Fonte: Adaptado de Moreira (2011). 
No quadro 1, têm-se um panorama resumido das principais e já consolidadas segmentações do Turismo, assim, pode-se entender que qualquer pessoa é um turista em potencial, pois todos possuem interesses que motivam e influenciam no processo de decisão sobre o que e a que preço pagar para conhecer um local.

Ao analisar os segmentos turísticos, destaca-se o crescimento que os chamados "destinosverdes" vêm alcançando nas últimas décadas. As pessoas cada vez mais desejam a fuga das rotinas e do estresse urbano e buscam conhecer destinações que possibilitam o contato e a interação com os ambientes naturais.

Este novo estímulo também pode ser observado no Brasil, país que possui uma tradicional tendência cultural direcionada ao turismo de sol e mar. Através da pesquisa realizada por Bacha e Strehlau (2009), verifica-se que a preferência para destinações campestres aumentam percentualmente quando o fator permanência é maior, ao passo que para os ambientes litorâneos, esta curva é inversamente proporcional.

Contudo, o Turismo em áreas naturais está intimamente relacionado com a interpretação, uma vez que o visitante desfrutará ainda mais do passeio ao entender as relações de uso historicamente formadas. Esta percepção deve vincular-se à comunidade local, sendo que seus moradores podem representar o elo entre os visitantes e a destinação, ressaltando os interesses locais em revitalizar manifestações, limitar o acesso de visitantes às particularidades entendidas como intocáveis, por isso, dignas de respeito.

Desta forma, observa-se a possibilidade de diversificação de fluxos de visitação através de Unidades de Conservação, visando preservar suas características histórico-culturais e oferecer subsídios econômicos para a comunidade do seu entorno. Diante deste contexto, entende-se que o Turismo pode ser uma alternativa para a conservação destas singularidades e para a promoção do cuidado com a natureza através de ações que demonstrem a fragilidade destes ambientes.

A necessidade em identificar a tipologia da atividade no processo de planejamento, é justificado pela ampla gama de características que cada segmento exige para que seja considerado, de fato, um atrativo turístico, e não mais um atrativo em potencial. Pretende-se, assim, propor oportunidades através do Turismo para a população residente no entorno do Parque Nacional dos Campos Gerais - PR (PNCG), caracterizado pelo enfoque do Ecoturismo.

Ainda que existam outras formas desta participação local, como é o caso do Turismo Rural e o Turismo Ecológico, o Ecoturismo vai além de utilizar o patrimônio natural. Suas responsabilidades ampliam-se para o patrimônio cultural, buscando construir uma consciência ambiental em seus praticantes, preocupando-se com a qualidade de vida das populações de entorno e com a sustentabilidade local.

O ecoturismo permite a realização do desejo em se encontrar com a natureza fora dos bosques e jardins projetados nas cidades. Para estes turistas, o contato com o ambiente in natura, os cantos dos pássaros, as tonalidades das flores aleatórias, o ar puro para ser respirado e a diversidade da natureza, impossíveis de serem captados no espaço urbano, representam os 
componentes essenciais para o re-estabelecimento da tranqüilidade e equilíbrio interior (SOIFER, 2005)

O Ministério do Turismo conceitua este segmento como:

Ecoturismo é o segmento da atividade turística que utiliza, de forma sustentável, o patrimônio natural e cultural, incentiva sua conservação e busca a formação de uma consciência ambientalista por meio da interpretação do ambiente, promovendo o bem-estar das populações. (BRASIL, 2010, p. 17).

Entendendo, portanto, que o Ecoturismo é um segmento capaz de produzir um novo dinamismo na organização espacial, tanto para a melhora da região com a implantação de novos serviços e infraestrutura, como também para possibilidade de especulação imobiliária, por exemplo, apoia-se em Santos (1997) quando o autor salienta que a configuração territorial dos espaços e as relações sociais constantemente construídas e reconstruídas, são necessários para a formatação do espaço turístico.

Stigliano (2009, p.68) reflete uma importante consideração sobre a distribuição dos efeitos positivos deste ramo, ao estabelecer:

A questão que se coloca é como impedir a concentração de benefícios nos níveis social e espacial, pois a socialização das perdas no modelo de desenvolvimento que não o sustentável é marcante. Levando-se em conta que o turismo pode reproduzir, tal como qualquer outro setor, as contradições dos processos de desenvolvimento, ressalta-se a pouca importância que tem sido dada à participação direta das comunidades nos projetos, planos e programas voltados ao seu desenvolvimento.

A atração que o Ecoturismo tem provocado no mundo é crescente. Os motivos são rotineiramente atribuídos à fuga do estresse vivenciado nos grandes centros urbanos, o contato com pessoas e a busca pelo verde e a apreciação da natureza. Indo além dos interesses da demanda, Boo (2001) trata de dois principais impactos positivos que o segmento produz na destinação, sendo: o desejo constante dos administradores em procurar levar um número cada vez maior de visitantes a parques e reservas, e também, a questão das comunidades próximas a áreas protegidas, beneficiadas pela ampliação de oportunidades de emprego trazidas com o Turismo.

Contudo, a autora ainda destaca outros impactos, que devem ser estudados e avaliados, buscando o equilíbrio entre a conservação e o desenvolvimento, ao esclarecer:

O impacto teórico do ecoturismo é bem conhecido. Os custos potenciais são a degradação do meio ambiente, as injustiças e instabilidades econômicas, as mudanças socioculturais negativas. Os benefícios potenciais são a geração de receita para as áreas protegidas, a criação de empregos para as pessoas que vivem próximo a essas áreas e a promoção de Educação Ambiental e de conscientização sobre a conservação (BOO, 2001, p. 34).

Sabendo que os projetos turísticos com enfoque em áreas naturais pertencem ao grupo de atividades que incentivam as pessoas a zelarem este patrimônio, entende-se também que faz-se 
necessário um certo grau de organização para a absorção dos benefícios gerados (BRANDON, 2001).

Esta organização pode se dar de variadas maneiras, desde que esteja sempre em comum acordo entre as necessidades / oportunidades com a atividade e em consonância com os desejos da comunidade local. Não seria prudente, por exemplo, estimular uma família a atuar como intérpretes em trilhas ou em um centro de visitantes, caso não tenham este interesse, pois se este contato inicial realizar-se de maneira inadequada, todo o passeio estará comprometido.

Portanto, a vontade em participar do Turismo deve ser despertada de acordo com as aptidões e habilidades existentes em cada pessoa da comunidade. Somente desta maneira, a comunidade local irá compreender, respeitar e garantir seu crescimento com serviços destinados aos visitantes. Western (2001, p.20) prevê ainda que a "conservação e o turismo que neguem os direitos e interesses das comunidades locais estão fadados ao fracasso, quando não considerados totalmente ilegais".

\section{Envolvimento da Comunidade e Turismo}

Caso a atividade atue em conjunto com o seu entorno, seus impactos positivos e demais benefícios como a inclusão social e o desenvolvimento local poderão de fato ocorrer. Na medida em que a comunidade local tiver possibilidade de trabalhar com o Turismo, maiores serão as oportunidades geradas sob a forma de vantagens competitivas para o setor. Sobre isso Barretto (2003, p.99) destaca:

O desenvolvimento do turismo só será possível na medida em que houver uma distribuição de renda que permita que segmentos cada vez mais amplos da população possam viajar. (...) os efeitos benéficos só acontecerão na medida em que os segmentos maiores da sociedade beneficiem-se do efeito multiplicador, através de melhores salários.

O efeito multiplicador da atividade trata da relação em cadeia produzido pelo gasto deixado pelo visitante em suas viagens. Pode-se exemplificar este trâmite através do pagamento de diárias em hotéis, onde o lucro não ficará apenas neste hotel, mas será repassado também aos fornecedores de insumos, de alimentos e bebidas, lavanderias e demais prestadores de serviços. Este ciclo permite a geração de novos postos de trabalho diretos e indiretos, e, a destinação como um todo, torna-se mais competitiva.

Porém para que o Turismo e o desenvolvimento comunitário se consolidem, cabe também salientar que esteja organizada de forma que sua sustentabilidade não seja afetada por qualquer motivo. Diante disso, a OMT (2012) define que os princípios da sustentabilidade referem-se ao turismo comprometido com os impactos atuais e futuros, sobre a esfera social, econômica e 
ambiental, preocupando-se também com as necessidades dos visitantes, das empresas do setor e com as comunidades anfitriãs ${ }^{1}$.

Portanto, a sustentabilidade deve ser considerada como elemento primordial dentro do planejamento de um local onde se pretende desenvolver o Turismo, pois esta é a base fundamental que irá nortear o desenvolvimento da destinação, fazendo com que os recursos necessários para sua manutenção possam ser provenientes da si própria.

Sendo ainda o Turismo uma atividade que possui poder de agregar valor junto ao patrimônio, ressaltando a compreensão de aspectos culturais e sociais alheios ao cotidiano dos visitantes, portanto capazes de mobilizar interesse de visitação, Barretto destaca (2000, p. 29-30):

Fora do patrimônio arquitetônico, existem outras peças de origem histórica, pertencentes ao cotidiano das populações, que geralmente se encontram nos museus. Há também uma enorme variedade de manifestações da cultura imaterial, chamada simbólica pela antropologia, entre as quais podem ser citadas as danças, a culinária, o vestuário, a música, a literatura popular e a medicina caseira, que despertam o interesse de turistas não institucionalizados.

Portanto percebe-se que são diversas as oportunidades para a utilização destes aspectos com potencial para ampliar o interesse do fluxo emissivo, nos mais diferentes segmentos do turismo. Contudo, este diferencial atrativo não deve ser interpretado como uma forma de resistência à modernidade pelas comunidades, mas sim como um modelo de comportamento, de rituais simbólicos e relações interpessoais singulares a outras localidades, por isso, motivo de respeito e conhecimento e inserção na atividade.

A inclusão de representantes comunitários merece destaque, pois, caso os destinos com ênfase nos atributos culturais não reconheçam os impactos que os moradores serão submetidos, podem ocorrer perdas no modo de viver, onde procurar-se-á apenas agradar ao turista, acarretando assim, em uma artificialização da paisagem. De acordo com estudos de Farias (2002, p. 65), pode-se compreender a maneira em que os agentes da comunidade devem contribuir com o Turismo:

É sabido que as comunidades constroem representações cognitivas, mapas mentais que orientam suas atividades cotidianas. Outras representações cognitivas se formam para tornar compreensivas as experiências e a relação com o meio ambiente e a cultura. Com essas representações, as pessoas reinventam seus mundos, mantendo ou transformando o legado de seus antepassados.

Desta maneira, entende-se que o Turismo não irá transformar uma localidade visando apenas para seu uso, mas irá sim, valorizar seu potencial de acordo com as experiências que a comunidade local julgar relevante e apta à comercialização, podendo alocar demais recursos que contribuirão para manter esses centros em atividade cotidiana, o que acaba enriquecendo ainda mais a experiência do visitante.

\footnotetext{
${ }^{1}$ Tradução livre do autor. Refere-se ao original em inglês: "Tourism that takes full account of its current and future economic, social and environmental impacts, addressing the needs of visitors, the industry, the environment and host communities" (OMT, 2012).
} 
Esta experiência remete-se ao contraste das destinações já massificadas, também conhecidas como não-lugar. Pode-se explicar esta definição através de Rodrigues (1997, p.32), onde: "produz-se no espaço global um lugar, que nega o local, sendo, portanto, um não-lugar. Nesse caso o turista viaja falsamente, sem sair do seu lugar, quase nada acrescentado à sua experiência pessoal". Assim, comparando os efeitos da globalização atual, destinos com propostas diferentes a aqueles em que podem ser encontrados em qualquer estado ou nação, tendem a destacarem-se e a crescerem, auxiliando assim na economia dessas destinações.

Assim, o envolvimento da comunidade local, ou de representantes definidos pelos próprios moradores do núcleo receptor deve ser estimulado e suas decisões necessitam serem respeitadas e vinculadas no planejamento turístico da destinação. Respeitando esta condição, os objetivos do Ecoturismo começam a ser alcançados, já que os visitantes esperam sair de suas casas para apreciarem algo exótico, com traços culturais próprios e dinâmicas de relações sociais singulares que ampliem o universo da viagem (BOO, 2001).

Além disso, a comunidade local precisa estar consciente e de acordo com as mudanças que irão acontecer no seu cotidiano, desta forma haverá uma diminuição ou como é desejável, uma anulação da repulsa pelo fluxo contínuo de pessoas entre suas moradias, que trazem novos hábitos, geram mais resíduos, provocam uma sensação de superioridade por estarem "sempre" em férias, etc.

Preocupado com esta questão, o World Wild Found for Nature - WWF (2003) publicou em sua cartilha "Manual de Ecoturismo de Base Comunitária: Ferramentas para um planejamento responsável" algumas considerações acerca da capacitação comunitária para o atendimento ao visitante, visando a qualidade do serviço e o benefício dos moradores. Concorda-se ainda com a visão deste órgão sobre a comunidade local, quando explica que:

Pessoas da comunidade que têm conhecimentos sobre as áreas naturais podem contribuir no desenvolvimento e na operação do produto ecoturístico. Podem ainda ser capacitados para atuar como guias ou assistentes de pesquisas de campo, pois ninguém conhece melhor sua área do que o próprio morador. Portanto, além de ser fonte de informações, a comunidade local pode contribuir na busca de informações. Deve ser ainda uma das maiores beneficiadas pelas pesquisas. Para isso deve ser consultada e informada sobre a proposta da pesquisa e ter acesso aos respectivos resultados. (WWF, 2003, p.417).

Com o reconhecimento, portanto, da população residente no núcleo receptor sobre os fatores que estarão expostos em conjunto com os visitantes, cientes dos benefícios gerados pelo Turismo e suas implicações planejadas de curto à longo prazo, inicia-se o processo de sustentabilidade, vital para o Ecoturismo.

A preocupação demonstrada pelo WWF (2003) é pertinente no que tangencia a minimização dos efeitos negativos e direciona trabalhos em campo. Esta valorização pelo local e sua busca de dados que correspondem à realidade vivida por estas pessoas são grandes diferenciais neste segmento. 


\section{Parque Nacional dos Campos Gerais - PNCG}

Com o gradual aumento da preocupação mundial sobre a proteção de áreas naturais, decorrente principalmente da extinção de inúmeras espécies e redução da biodiversidade, a criação de unidades de conservação visa possibilitar a recuperação de áreas naturais e a manutenção de recursos ambientais.

De acordo com Ruschmann (1997) este impulso tem um efeito positivo contra o que a autora denomina como uma falta de "cultura turística", onde o visitante estaria condicionado ao entendimento que seu tempo livre é sagrado e por terem pago, independente da quantia, podem usufruir como bem entendem do local visitado. Ruschmann (1997, p. 23) demonstra esta vertente ao comentar:

Outras formas de turismo estão sendo propostas, a fim de conter os impactos negativos da atividade e, além do (...) turismo brando e tranquilo, recebem a denominação de "alternativo", "responsável", "ecológico" e, mais recentemente, de "turismo sustentável". (...) o que os caracteriza são as viagens individuais, as atividades relacionadas com a natureza, o alojamento em estabelecimentos, com serviços personalizados e, às vezes, até realizado pelos próprios turistas.

Sabendo que a preocupação com a sustentabilidade é um dos principais pilares do Ecoturismo, as unidades de conservação representam um produto a ser utilizado pelo Turismo com face ao desenvolvimento e crescimento local, agregando valor e permitindo ainda, a preservação e recuperação da natureza.

Neste contexto, a Lei no 9.985 (BRASIL, 2000), que criou o Sistema Nacional de Unidades de Conservação - SNUC, sistema este que estabelece critérios e normas para que se possa instituir, implantar e gerir unidades de conservação no país, corrobora com esta preposição. Esta Lei abrange dois grupos de proteção:

Unidades de Proteção Integral, onde o objetivo tange a proteção da natureza e seu uso restrito à atividades indiretas, como é o caso do turismo em unidade de categoria Parque Nacional, e;

Unidades de Uso Sustentável ${ }^{2}$, onde é possível a utilização parcial dos recursos naturais, como exemplifica-se com as Reservas Extrativistas e sua exploração extensiva por comunidades tradicionais (BRASIL, 2000).

Diante deste panorama, na região dos Campos Gerais no Paraná é possível encontrar nos limites dos municípios de Ponta Grossa, Carambeí e Castro os últimos remanescentes do Bioma Mata Atlântica, composto por Floresta Ombrófila Mista e Campos Sulinos, sendo estas, as principais formações fitogeográficas naturais do sul do país (BRASIL, 2006). Esta formação representa também um dos mais importantes patrimônios naturais do Paraná e motivador para a instituição do Parque Nacional dos Campos Gerais - PR.

\footnotetext{
${ }^{2}$ Também fazem parte deste grupo as UC's: Área de Proteção Ambiental; Área de Relevante Interesse Ecológico; Floresta Nacional; Reserva de Fauna; Reserva de Desenvolvimento Sustentável e Reserva Particular do Patrimônio Natural.
} 
O PNCG é composto por 21.286 hectares e está divido em dois polígonos com diferentes tamanhos, tendo no setor norte 18.135 ha e o sul com 3.151 ha, com limite estipulado em $500 \mathrm{~m}$ para a zona de amortecimento ${ }^{3}$ (BRASIL, 2006), conforme pode-se observar na Figura 1.

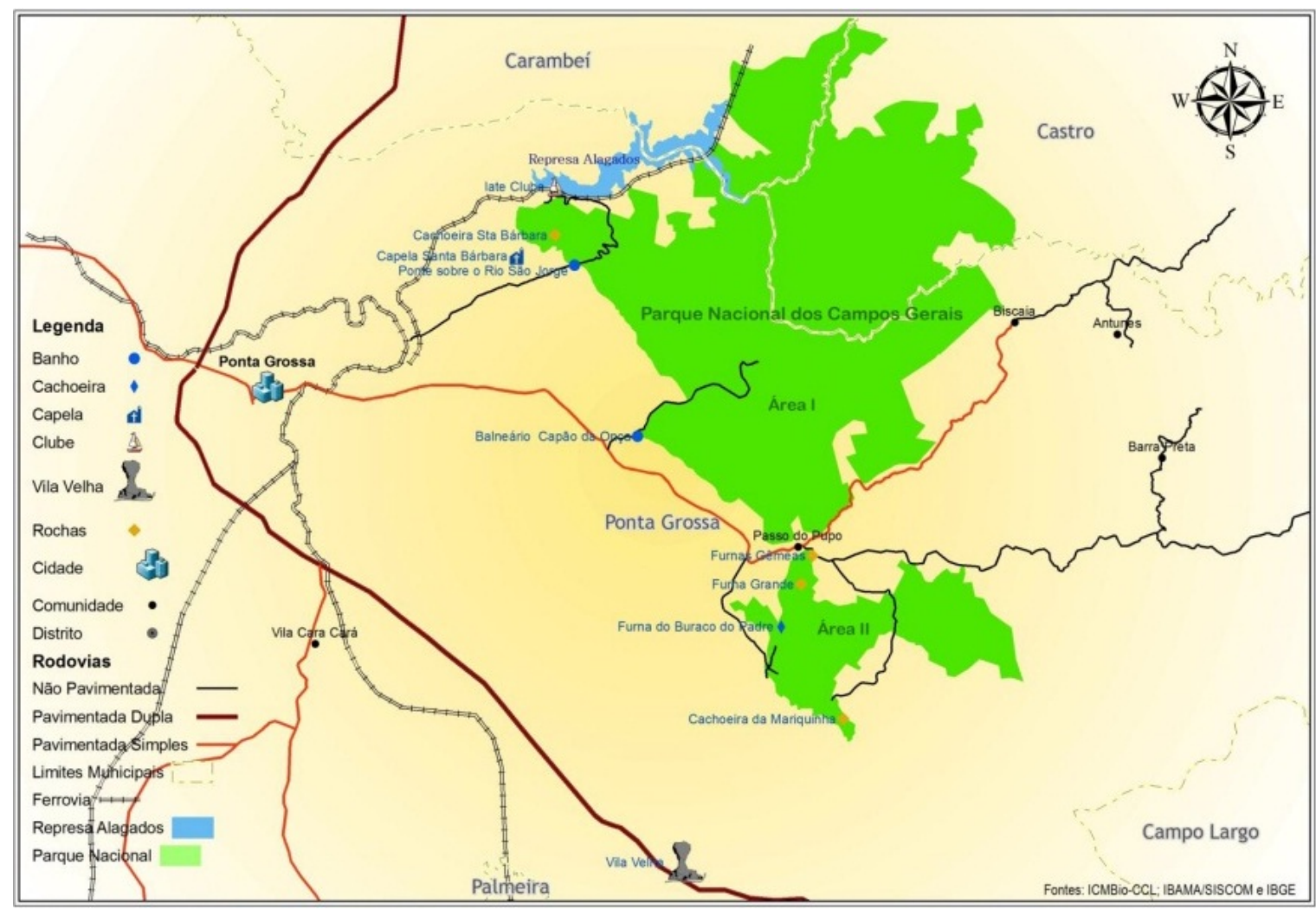

Figura 1: Disposição das áreas do Parque Nacional dos Campos Gerais. Fonte: ICMBio, 2012.

Criado em 23 de março de 2006 por meio do Decreto Lei s/nº do Diário Oficial da União de 24/03/2006, atualmente a gestão do PNCG está vinculada ao Instituto Chico Mendes de Conservação da Biodiversidade - ICMBio, órgão este responsável também pelo levantamento do inventário patrimonial das áreas que compõem o Parque, para futura indenização e desapropriação aos proprietários destas terras, conforme estipula a legislação vigente (BRASIL, 2000).

Porém, os trabalhos do ICMBio vão além das desapropriações, cabendo ao Instituto agir de acordo com as determinações da Lei $n^{\circ} 9.985$ do Sistema Nacional de Unidades de Conservação, podendo desta maneira: propor, implantar, gerir, proteger, fiscalizar e monitorar as UCs instituídas pela União (ICMBio, 2012).

Neste local, é possível encontrar atrativos ambientais, geológicos e naturais singulares, por isso, capazes de motivar o interesse também para demanda e fluxo turístico, podendo serem citados: sua a cobertura vegetal com a presença de florestas e várzeas naturais; os afloramentos rochosos da Formação Furnas e o Arco de Ponta Grossa e; locais de uso público, com relevante interesse turístico, como a Cachoeira da Mariquinha e do Rio São Jorge.

\footnotetext{
${ }^{3}$ A zona de amortecimento situa-se no entorno de uma unidade de conservação e tem como objetivo filtrar ou diminuir os efeitos externos, como poluição e atividades econômicas de alcançarem a área protegida. 
De acordo com o mapeamento realizado por Almeida e Moro (2007, p.119) a fragmentação vegetal que compõe o mosaico do PNCG assume duas formas distintas, no sentido leste - oeste, sendo formado respectivamente por florestas e várzeas do primeiro planalto e por capões, campos e brejos da altitude no reverso da Escapa Devoniana no segundo planalto, representando uma área de $46,1 \%$ da área total que forma o Parque com cobertura florestal.

Nas áreas do Parque Nacional dos Campos Gerais existem ainda locais de beleza cênica, podendo ser citados o Buraco do Padre (Figura 2), uma furna com aproximadamente $30 \mathrm{~m}$ de diâmetro e $40 \mathrm{~m}$ de profundidade que recebe as águas do Rio Quebra Pedra que formam uma cascata em seu interior (MELO; LOPES; BOSKA, 2009); as Dolinas Gêmeas, crateras circulares sem água em seu interior e com presença de vegetação natural; o cânyon do Rio São Jorge, com cursos d'água que formam cachoeiras (PREFEITURA MUNICIPAL DE PONTA GROSSA, 2012), entre outras falhas geológicas. Estes atrativos possuem grande potencial para a prática do Ecoturismo e do Geoturismo, podendo fomentar assim a atividade e representar uma nova fonte de renda para a toda a região.

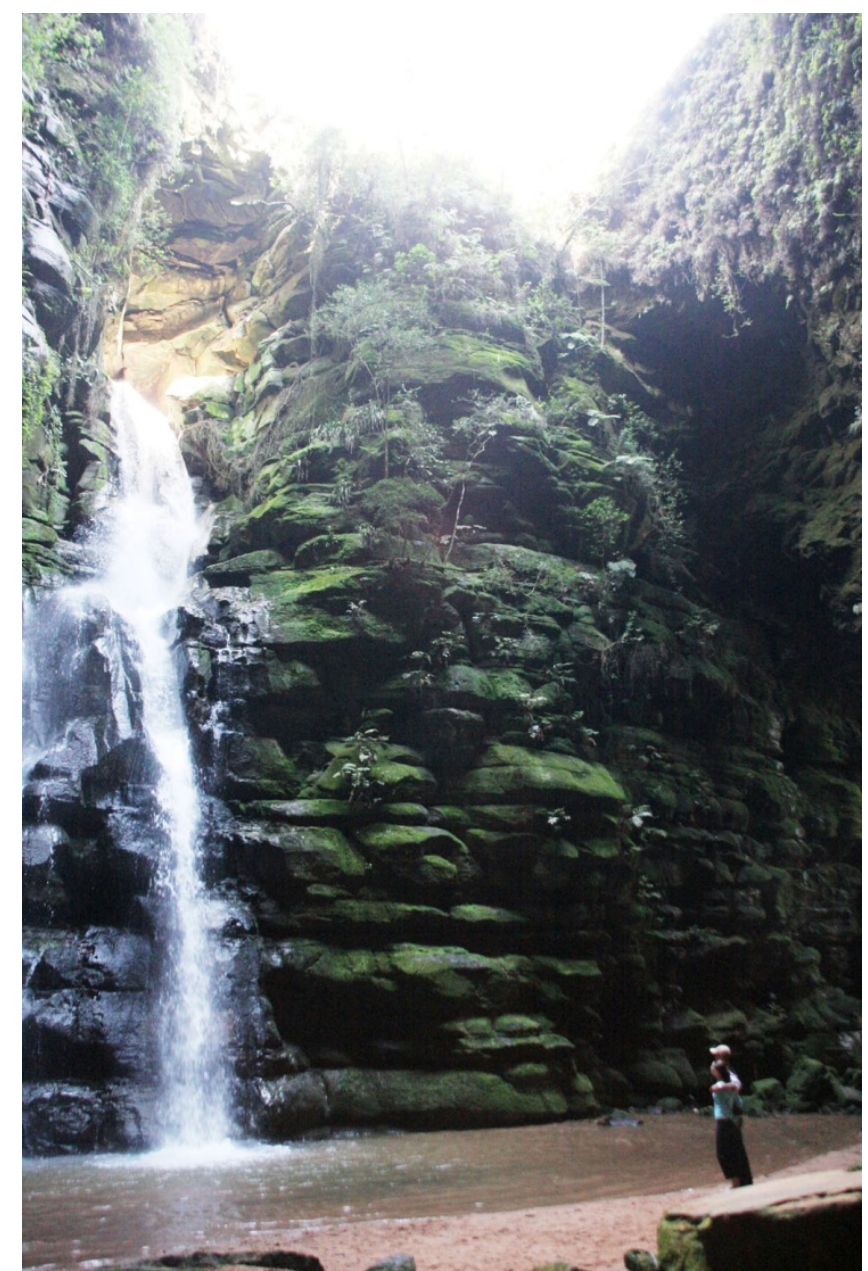

Figura 2: Buraco do Padre. Fonte: Prefeitura Municipal de Ponta Grossa, 2012.

As características geológicas presentes na área do PNCG são responsáveis pela maior parte de sua atratividade turística, formados pelas fraturas da Bacia Sedimentar do Paraná e 
posterior erosão que permitiu o afloramento das rochas e arenitos (MELO; LOPES; BOSKA, 2009).

Entretanto, de acordo com texto de seu Decreto de criação, o Parque Nacional dos Campos Gerais deve também colaborar para que atividades que envolvam a realização de pesquisas científicas, o desenvolvimento de atividades de educação ambiental e o Turismo ecológico (BRASIL, 2006).

Tendo consciência sobre a problemática que envolve a utilização de espaços naturais, enquanto um recurso escasso e em processo constante de deterioração, vem sendo discutida ao longo das últimas décadas, sendo nos últimos anos objeto de maior interesse também da sociedade civil. Os principais elementos constituintes deste problema são oriundos do próprio modo de organização social, onde se preconiza o infinito acúmulo de capital.

Os reflexos mais facilmente identificáveis deste problema são: a desigualdade social, aumento nas taxas de desemprego, esgotamento de matéria-prima não renovável, perda tanto da biodiversidade como da geodiversidade ${ }^{4}$, entre outros. Assim, o interesse pela Educação Ambiental também merece destaque, pois com esta atividade a capacitação constante de visitantes em UCs colabora para a construção de uma consciência ambiental nestes sujeitos.

De acordo com a Lei n 9.795/99 (BRASIL, 1999), que trata da Política Nacional de Educação Ambiental (PNEA), considera-se educação ambiental:

Os processos por meio dos quais o indivíduo e a coletividade constroem valores sociais, conhecimentos, habilidades, atitudes e competências voltadas para a conservação do meio ambiente, bem de uso comum do povo, essencial à sadia qualidade de vida e sua sustentabilidade.

A preocupação ambiental no país tem início a partir dos anos $80 \mathrm{com}$ a criação do Programa Nacional de Educação Ambiental (Pronea) em 1984 e a inclusão deste item no texto da Constituição Federal de 1988. Entre 1992 e 1997 a Educação Ambiental (EA) passa a compor agendas de discussão até finalmente ser criado o Órgão Gestor da Política Nacional da EA, em conjunto com o Ministério da Educação e Ministério do Meio Ambiente, em 2003 (CARVALHO, 2006).

Diante do entendimento e da ciência de que toda ação gera impacto, entende-se que a Educação Ambiental precisa ser colocada em prática seja por meios formais ou não-formais por todas as pessoas que estão ou entrarão em contato com sítios, parques ou Unidades de Conservação, uma vez que estes espaços possuem fragilidades que podem sofrer diferentes níveis de degradação, oscilando entre às camadas mais leves até as irreparáveis (BAPTISTA; AMARAL, 2011).

Desta forma, devido à abrangência e importância que a Educação Ambiental proporciona, verifica-se que sua atuação em conjunto com demais áreas do conhecimento, tais como a Ecologia, a Biologia, a Geografia, o Turismo, etc., resultará na ampliação seus benefícios, uma

\footnotetext{
${ }^{4}$ Entende-se como geodiversidade, os aspectos não vivos presentes no planeta, bem como a evolução natural destes aspectos que atualmente estão originando novas formas (BRILHA, 2005). 
vez que ao tratar este tópico de forma transversal, a absorção de seus conceitos e da responsabilidade socioambiental será maximizada. Corroborando com esta questão, Loureiro (2009, p. 53) afirma que "o educador ambiental, ao implementar processos interdisciplinares e ao trabalhar com temas geradores, não pode isolá-los da realidade complexa que os formam".

De forma a complementar os preceitos da Educação Ambiental, observa-se também que a interpretação do patrimônio poderá contribuir como uma ferramenta transformadora de comportamentos e atitudes ao vincular esta com os produtos turísticos, seja este ambiental, edificado ou cultural, analisado sob a ótica de um atrativo.

De acordo com Beni (2004, p. 302) atrativo turístico é "todo lugar, objeto ou acontecimento de interesse turístico que motiva o deslocamento de grupos humanos para conhecê-los". Para melhor segmentar o conceito de atrativo ambiental, autor cita alguns exemplos, como serras, chapadas, dunas, etc.

Estes locais vêm recebendo grande aumento no interesse de visitação, que cada vez mais é procurado por turistas em todo o globo. Contudo, a compreensão destes espaços está vinculada às técnicas de interpretação do patrimônio, responsáveis por desmistificar a natureza e consequentemente, enriquecer a experiência do visitante.

De acordo com Tilden (p. 8, 1977), considerado pioneiro no estudo da interpretação do patrimônio, conceitua-se este serviço como: "uma atividade educativa que visa revelar significados e relações através da utilização de objetos originais, da experiência e por meios ilustrativos, ao invés de simplesmente comunicar a informação factual" ${ }^{5}$.

A interpretação, de acordo com o autor, deve estar intimamente em contato com a emoção e os sentimentos das pessoas, de tal modo que seja possível para o visitante reconhecer o âmbito coletivo da biodiversidade local, sendo aquele espaço mais do que uma fonte de matéria-prima, mas um elemento de vida.

Esta tendência tem sida utilizada em diversos projetos e estudos, o que demonstra sua importância para o desenvolvimento sustentável de unidades de conservação. Tendo por fundamento que o serviço de interpretação distingue a ciência da arte, ressalta-se que este trabalho deva transmitir emoção nas mensagens expostas, envolvendo assim os sentimentos dos visitantes (TILDEN, 1977).

Murta (2002) destaca o exemplo de Stonehenge na Inglaterra, atrativo de construção e funcionalidade incerta ainda na atualidade. Neste local, através do uso de audiofones, os visitantes podem escutar histórias e indicações que ajudam a entender o sítio, com informações sobre as rochas, lendas e hipóteses geradas ao longo de estudos e pesquisas. Este meio interpretativo, disponível em vários idiomas, amplia o olhar do visitante, podendo ser utilizado por crianças e adultos, fazendo-os aprender mais com esta experiência.

\footnotetext{
${ }^{5}$ Tradução livre dos autores. Refere-se ao original em inglês: "An educational activity which aims to reveal meanings and relationships through the use of original objects, by firsthand experience, and by illustrative media, rather than simply to communicate factual information". (TILDEN, 1977, p. 8).
} 
Pode-se citar diversos meios interpretativos, utilizando alta tecnologia, placas, painéis, sinalizações, entre outros. Alguns casos como a Trilha do Jubileu em Londres, a sinalização urbana em Antonio Prado - RS e os painéis interpretativos espalhados por locais históricos na Inglaterra (MURTA; ALBANO, 2002), são bons exemplos. Infelizmente no Brasil ainda são poucos os trabalhos de sinalização e de painéis interpretativos nos mesmos moldes europeus ou americanos, predominando o uso de placas e folders com muito texto e poucas imagens, incapazes de prender a atenção do visitante.

Além da interpretação, o potencial da Educação Ambiental como uma atividade catalisadora para mudanças de hábitos sociais, em conjunto da interpretação do patrimônio, pode portanto, servir de apoio em relação aos aspectos referentes à cultura, à biodiversidade e à geodiversidade (contemplando a Geologia e a Geomorfologia), por isso, valorizada enquanto objetivo proposto pelo plano de manejo de UCs.

O plano de manejo, de acordo com a Lei 9.985 é conceituado como um:

Documento técnico mediante o qual, com fundamento nos objetivos gerais de uma unidade de conservação, se estabelece o seu zoneamento e as normas que devem presidir o uso da área e o manejo dos recursos naturais, inclusive a implantação das estruturas físicas necessárias à gestão da unidade (BRASIL, 2000).

Portanto, neste documento oficial que orienta o curso de atividades das unidades de conservação, as questões que envolvem a comunidade de entorno são discutidas. Indo além do Plano de Manejo, esta Lei garante ainda a participação local na criação, implantação e gestão de UC's, quando ressalta o objetivo do Parque em "promover sua integração à vida econômica e social das comunidades vizinhas".

\section{METODOLOGIA}

Para responder os objetivos propostos, esta pesquisa foi fundamentada em uma análise qualitativa da realidade (BAUER; GASKELL, 2002), valendo-se de observação em campo, além de utilizar uma "composição interdisciplinar" que contém conceitos da geografia, sociologia, economia e do Turismo.

A pesquisa qualitativa foi determinada por prevalecer à pluralidade de opiniões e sentimentos em relação ao tema, visando compreender a percepção local frente às mudanças futuras que devem ocorrer na região (TRIVIÑOS, 1987).

Seguindo orientação de Dencker (1998), a pesquisa foi elaborada com as características de investigação exploratória e seccional - onde analisa-se o fenômeno apenas por um determinado período de tempo, com perguntas abertas e fechadas em questionário semiestruturado abordando o Parque Nacional dos Campos Gerais - PR, portanto, com um recorte fixado a partir de 23 de março de 2006, data da criação desta UC. 
As entrevistas foram concentradas no vilarejo Passo do Pupo, uma das quatro comunidades no entorno do PNCG, que congrega: Cerradinho, Cerrado Grande e Biscaia. A escolha por este local em detrimento de outras se deu por este local estar em consonância com os objetivos do ICMBio, gestor da UC, que planeja a construção da infraestrutura receptiva do Parque neste local, devendo portanto, representar o futuro portão de entrada dos visitantes.

Para Triviños (1987, p. 145-6), a "entrevista semiestruturada é um dos principais meios que tem o investigador para realizar a Coleta de Dados". Devido à complexidade do tema, a opção por esta técnica foi considerada como de maior confiabilidade para a compreensão do fenômeno investigado pela visão dos pesquisadores.

Para a coleta de dados no Passo do Pupo, inicialmente idealizou-se a execução de entrevista primária com algum morador que representasse liderança comunitária, como estratégia metodológica para o desenvolvimento e aplicação dos questionários seguintes, conforme orienta Meihy (2005). Contudo, esta ação não tornou-se válida devido a não existência de organizações político-sociais local.

Assim, foram desenvolvidos os questionários abordando o PNCG e a atividade turística, aplicados em 21 residências onde apenas um morador foi entrevistado. Sobre o primeiro tema, a entrevista buscou identificar o entendimento local sobre a motivação de criação do Parque e os atrativos presentes neste. Para o segundo tema, o objetivo concentrou-se em descobrir o interesse pessoal em atuar no turismo, e em caso afirmativo, com o que gostaria de trabalhar, e por fim, questionou-se o que deveria ser melhorado ou implantado para atender os visitantes.

O quantitativo de entrevistas utilizado pelo recorte foi determinado pelo número de residências com pessoas em casa durante os dias 02 à 04 de novembro de 2012, não sendo possível estimar a porcentagem deste sobre o número total de moradores uma vez que não há dados oficiais sobre a comunidade.

Para a análise dos dados, foi utilizada uma composição entre: análise documental, pesquisa bibliográfica, observação e resultados obtidos nas saídas de campo. Cabe ressaltar a importância e relevância em realizar um diálogo entre o levantamento teórico com os resultados obtidos nas entrevistas, pois desta forma torna-se mais factível e imparcial sua compreensão. Esta abordagem permite ainda que a fundamentação de novas hipóteses e sugestões possam ser geradas e colocadas em prova.

\section{RESULTADOS E DISCUSSÃO}

Nenhuma forma de identificação das pessoas entrevistadas foram coletadas nos questionários aplicados, sendo possível apenas elencar seu sexo com fins estatísticos, representando um total de 5 homens e 16 mulheres, sendo que uma das mulheres entrevistadas, optou por não responder às perguntas. 
Para a sistematização dos resultados encontrados, optou-se por agrupá-los em categorias, conforme segue:

- Porque o Parque Nacional dos Campos Gerais foi criado? - objetivou-se compreender a percepção local sobre os motivos que levaram à criação do PNCG.

- Quais são os principais atrativos do Parque? - além de identificar os atrativos presentes na área de proteção desta UC, as respostas sugerem o reconhecimento dos indivíduos como locais de interesse turístico.

- O que precisa ser melhorado ou implantado para atrair mais visitantes? buscou-se identificar o olhar dos sujeitos sobre as deficiências locais para o atendimento de turistas. As respostas desta questão representam necessidades fundamentais, já que os moradores da comunidade convivem diariamente com estes problemas.

- Existe interesse em trabalhar com atividades voltadas ao turismo? - esta pergunta visou descobrir a vontade da comunidade local em atuar na atividade turística. Para os sujeitos que responderam afirmativamente esta questão, também perguntamos de que forma desejavam participar do segmento.

Ressalta-se que os entrevistados tinham a oportunidade de citar mais de uma resposta, exceção parcial apenas para a questão relacionada ao interesse na atividade turística, em que o entrevistado respondeu ou afirmativamente ou negou esta oportunidade, para em um segundo momento poder citar quantas variáveis desejasse para complementar sua resposta.

\section{Motivos de Criação do Parque Nacional dos Campos Gerais}

Nos resultados levantados, dez pessoas disseram desconhecer a razão pela qual o Parque foi criado, representando um percentual de $50 \%$ da amostra. Este número nos chama atenção por demonstrar que a comunidade não está participando ou recebendo informações sobre esta unidade de conservação. As principais hipóteses geradas a partir deste dado podem indicar que o número limitado de funcionários no escritório do ICMBio é insuficiente para atuar em todas as necessidades do Parque e que o poder público dos municípios em que o Parque está situado, especialmente em Ponta Grossa - PR, ainda não preocupou-se com os efeitos à que esta população está sujeita.

Para o grupo que sugeriu motivações para a implantação do PNCG, doze respostas estiveram voltadas à proteção ambiental, sendo respectivamente: 4 para preservação; 3 para proteção; 3 para desmatamento; 1 para reserva e 1 para mata. As incidências direcionadas à outros aspectos referem-se à: 2 para proteção da água; 2 para proteção dos animais e 1 para a qualidade do ar. 


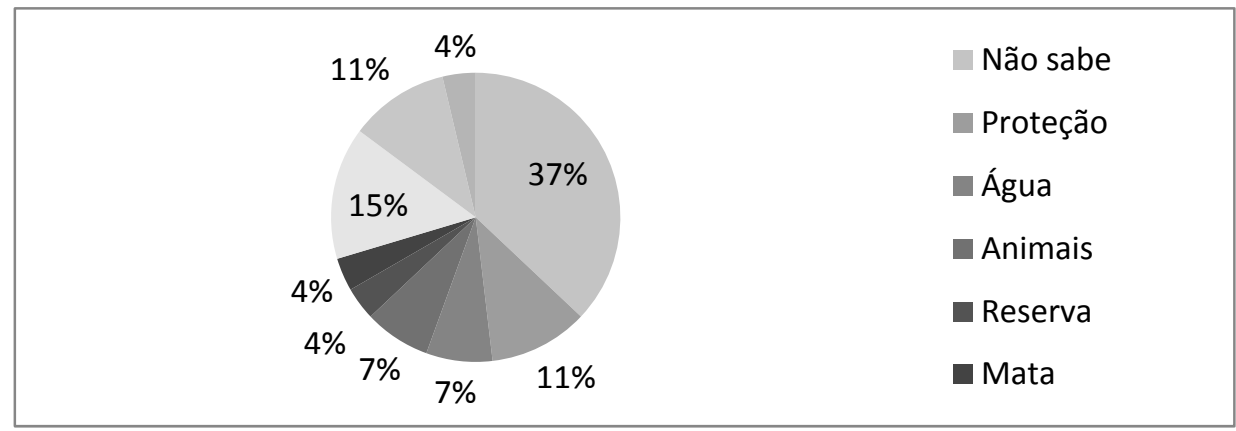

Figura 3: Percepção sobre a criação do PNCG.

\section{Atrativos presentes no PNCG}

Percebeu-se com estas respostas o reconhecimento local pelos atrativos turísticos localizados próximos às moradias da comunidade do Passo do Pupo apenas, o que corrobora com o desconhecimento de informações básicas sobre o PNCG. Em nenhum questionário, os atrativos do polígono norte foram citados, cabendo ainda, por um entrevistado, a associação da Caverna Olhos D'água, fora dos limites do Parque, como integrante deste.

As respostas obtidas somam 16 indicações para a Cachoeira da Mariquinha, 12 para o Buraco do Padre e 10 para as Furnas. As demais opiniões remeteram-se à paisagem, por três entrevistados, onde "capão", por um destes, foi o termo utilizado. Com uma resposta cada tivemos: Cachoeira da Boa Sorte e não soube responder.

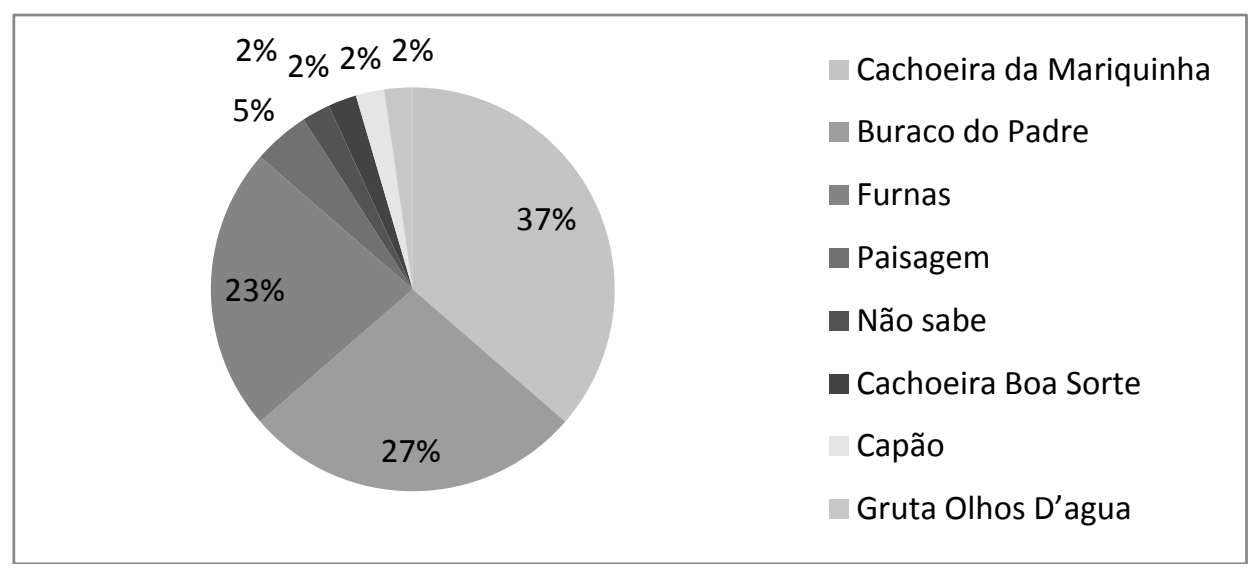

Figura 4: Atrativos do PNCG.

Para o Parque Nacional dos Campos Gerais, os atrativos que são facilmente identificáveis como potenciais produtos turísticos podem ser sintetizados em: ecoturismo, trilhas, geoturismo, birdwatching, atividades de contemplação e prática de esportes radicais como o rapel, cachoeirismo e escalada. Desta forma, sabe-se que os moradores já possuem a visão do que o Parque deve utilizar nas áreas de uso público.

Entende-se, diante deste cenário, que os preceitos da interpretação ambiental podem ser favoráveis ao trabalho de Educação Ambiental no Parque Nacional dos Campos Gerais - PR permitindo que esta UC atente para tal objetivo fixado em seu Decreto de criação. A elaboração 
de jogos, mapas e peças artesanais que tragam informações sobre aspectos gerais do Parque, representam opções viáveis e que agregam também valor no produto turístico, fazendo o turista gastar mais e contribuir com a economia local.

\section{Necessidades e deficiências na infraestrutura do Parque}

Relatando sobre o que acreditavam que precisaria sem implantado ou melhorado para atrair mais visitantes, uma resposta repetida por quatro vezes nos chamou atenção. Os moradores disseram que é preciso a instalação de um posto de saúde, mesmo ao reiterarmos que era para melhor atender ao turista. Analisamos esta questão sob o ponto de vista de Maslow (1970), onde a hierarquia das necessidades humanas exige a satisfação de níveis básicos para que então novas demandas sejam geradas. Desta forma, a hipótese de rejeição pela instalação de infraestrutura turística nesta comunidade, deve ser considerada.

Para aqueles que responderam sobre o turismo, as vias de acesso (estradas) somaram o maior índice de insatisfação, com onze ocorrências. Quatro pessoas não souberam opinar e o transporte público e sinalização tiveram duas afirmativas cada. As demais respostas foram: pontos de vendas, trilhas, sanitários, folder, limpeza, preservação, estrutura para acomodar turistas e infra-estrutura, com uma citação cada.

Apesar das respostas anômalas ao tema pesquisado, percebe-se um moderado nível de conhecimento sobre as necessidades turísticas que devem fazer parte da comunidade a curto e médio prazo.

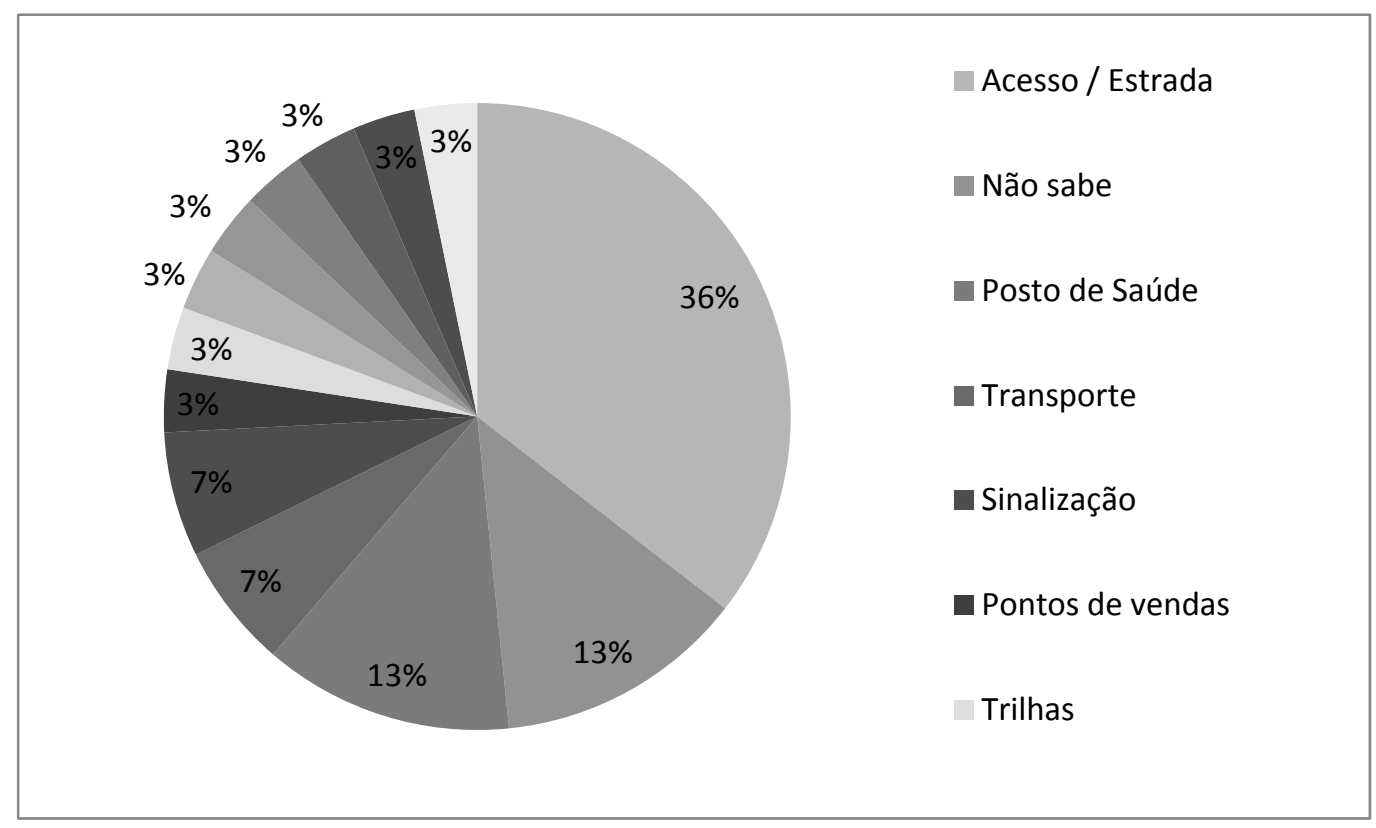

Figura 5: Necessidades para a infraestrutura.

De maneira a beneficiar os moradores, visando tanto seus aspectos ambientais, quanto suas necessidades econômicas, percebe-se que a atividade turística aliada a interpretação do 
patrimônio, pode ser implantada em Parques Nacionais e estimulada nesta área pesquisada, favorecendo assim sua manutenção, valorização e conservação, desde que ocorra de forma planejada, resultando assim na menor absorção de seus aspectos negativos e na maximização de seus impactos positivos.

\section{Desejo em Participar da Atividade Turística}

As respostas para esta questão foram de 14 entrevistados com interesse contra seis que negaram a oportunidade. Estes números fornecem um importante indicador para a composição do Plano de Manejo desta unidade de conservação, pois, ainda que os resultados desta pesquisa demonstrem dados preliminares, representam o início do preenchimento de uma lacuna nos estudos relacionados ao Parque Nacional dos Campos Gerais - PR.

Neste sentido, questionados sobre quais atividades gostariam de participar, a grande maioria (55\%) não soube se posicionar, enquanto duas pessoas que já trabalham com vendas de alimentos e bebidas disseram estar dispostas a ampliar suas ofertas para atender aos turistas. Outro entrevistado disse desejar atuar como guia ou condutor de visitantes no interior do Parque. Estas 14 respostas são equivalentes à $70 \%$ da amostra entrevistada, resultado expressivo, se analisado o contexto não favorável que o PNCG desperta na comunidade.

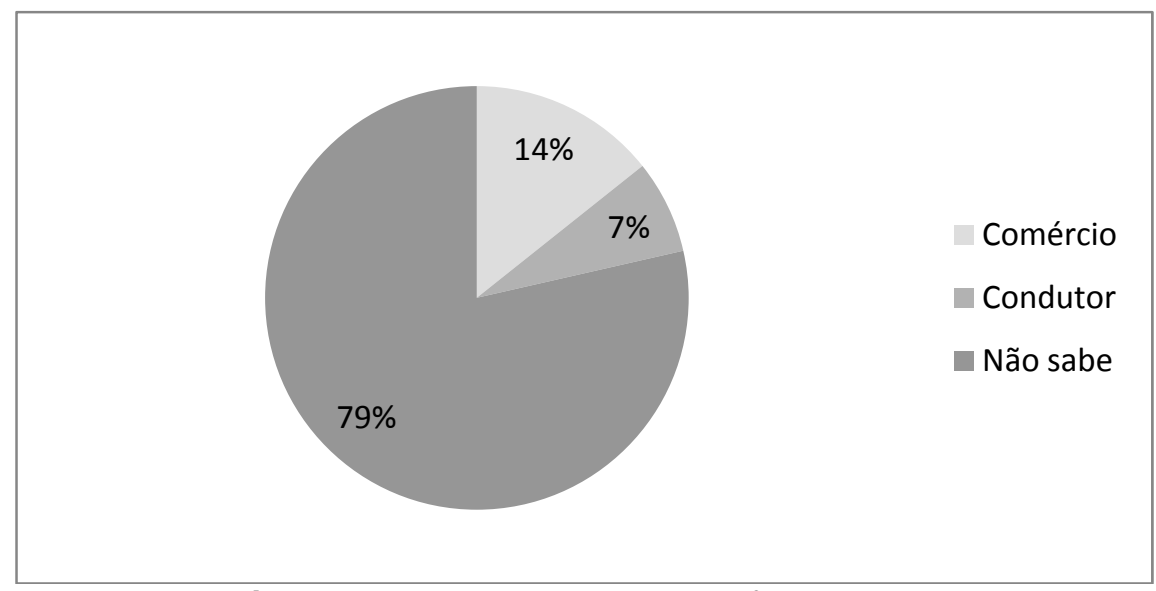

Figura 6: Necessidades para a infraestrutura.

Estando o Ecoturismo vinculado majoritariamente no contato direto entre visitantes e a natureza, a localização e o entorno do PNCG favorecem a multiplicação dos seus efeitos para que a comunidade residente também seja beneficiada pela atividade.

Desta forma, as oportunidades geradas com a aceitação dos moradores desta comunidade são consideradas essenciais para o desenvolvimento do PNCG, já que entre todos os vilarejos de entorno, o Passo do Pupo é o que melhor apresenta condições de abrigar o centro de visitantes, devendo ser, portanto, o portão de entrada dos visitantes nesta UC. 


\section{CONSIDERAÇÕES FINAIS}

O papel da comunidade local, percebida como uma esfera importante sob o ponto de vista do sistema de turismo (BENI, 2004) deve ir além do reconhecimento e da projeção econômica que é capaz de mobilizar. O visitante adepto do Ecoturismo valoriza as ações que envolvem os moradores locais, levando consigo impressões que contribuem para formar a imagem do passeio.

Percebe-se com a aplicação dos questionários e observações em campo que os moradores da comunidade do Passo do Pupo têm uma relação sentimental pelo espaço que vivem, e mesmo desconhecendo questões pontuais sobre o Parque Nacional dos Campos Gerais, não o rejeitam, estando desmotivados por sentirem-se excluídos do processo de implantação, sobretudo pela falta de informações que não chegam até estes.

Cabe destacar ainda, que este foi o primeiro contato que a comunidade teve com pesquisadores interessados em ouvi-los, causando em alguns momentos descobertas pessoais sobre o PNCG, quando nos foi perguntado se eles teriam que sair daquele local quando o Parque começar a receber visitantes de forma institucionalizada.

Estas dúvidas corroboram com a necessidade de ações por parte do ICMBio, no sentido de incluir as comunidades de entorno no contexto legal à que estão submetidos, demonstrando as estratégias que serão traçadas para o envolvimento local de forma a beneficiá-los nos níveis social, cultural e econômico.

Os principais motivos que corroboram com esta afirmação se devem à localização desta comunidade, situada entre os dois polígonos (norte e sul) do Parque, sua infraestrutura básica instalada, com acesso por via asfaltada, disponibilidade de energia elétrica, água tratada e linha telefônica, além destes moradores já manterem contato e prestarem algumas informações aos visitantes dos atrativos ali disponibilizados.

Como diagnosticado, para aqueles que mostraram-se favoráveis em utilizar o turismo como um serviço capaz de agregar de renda e desenvolvimento, poucos foram os moradores que já possuem uma visão de como aproveitar a atividade dentro de suas possibilidades.

Infelizmente não foi possível levantar as respostas em todas as residências edificadas na comunidade. A busca pelas respostas nas demais casas se deu por outras duas vezes, onde foram encontradas os mesmos locais fechados, impossibilitando neste momento, estabelecer os indicadores na totalidade do vilarejo do Passo do Pupo. Contudo, a investigação continuará sendo trabalhada, devido à importância em realizar um diagnóstico mais apurado e preciso da situação atual.

As estratégias futuras devem incluir, portanto, encontros para explicar como funcionam as diretrizes de unidades de conservação no que se refere ao seu entorno, a preocupação em multiplicar os efeitos positivos que o turismo gera, as atividades possíveis de serem desenvolvidas pelos moradores, a questão do uso público e o contato contínuo com visitantes ao redor de suas casas. 
Assim, entende-se que novas perguntas são geradas com este estudo preliminar, motivando por fim, a continuidade de investigações e análises de situação local, oportunidades e riscos potenciais e desenvolvimento de estudos visando promover o desenvolvimento sustentável desta unidade de conservação.

\section{REFERÊNCIAS}

ALMEIDA, C. G.; MORO, R. S.. Análise da cobertura florestal no Parque Nacional dos Campos Gerais, Paraná, como subsídio ao seu plano de manejo. Terr@ Plural, Ponta Grossa, v.1, n.1, p.115-122, 2007.

BACHA, M. L; STREHLAU, V. I. Uma tipologia para segmentação de hábitos de viagem das classes populares. Revista Turismo Visão e Ação, v.11, n. 2, p.175-200, 2009.

BAPTISTA, L.; AMARAL, J. G.. Educação ambiental e turismo: um enfoque sustentável à conservação de faxinais. In: ENCONTRO PARANAENSE DE EDUCAÇÃO AMBIENTAL, 13., Ponta Grossa, 2011. Anais. Ponta Grossa: UEPG, 2011. CD-ROM.

BARRETTO, M.. Manual de iniciação ao estudo do turismo. 13 ed. Campinas: Papirus, 2003.

BARRETTO, M.. Turismo e legado cultural. Campinas: Papirus, 2000. 96 p.

BAUER, M. W.; GASKELL, G.. Pesquisa qualitativa com texto, imagem e som: um manual prático. Petrópolis: Vozes, 2002.

BENI, M. C.. Análise estrutural do turismo. 10 ed. São Paulo: EdSenac, 2004.

BOO, E.. O planejamento turístico para áreas protegidas. In: LINDBERG, K.; HAWKINS, D. E.. Ecoturismo: um guia para planejamento e gestão. 3 ed. São Paulo: EdSenac São Paulo, 2001.

BRANDON, K.. Etapas básicas para incentivar a participação local. In: LINDBERG, K.; HAWKINS, D. E.. Ecoturismo: um guia para planejamento e gestão. 3 ed. São Paulo: EdSenac São Paulo, 2001.

BRASIL. 1999. Lei $\mathbf{n}^{\circ}$ 9.795, de 27 de abril de 1999. Institui a Política Nacional de Educação Ambiental. Diário Oficial da República Federativa do Brasil, Brasília, 28 abr. 1999.

BRASIL. 2000. Lei $\mathbf{n}^{\circ} \mathbf{9 . 9 8 5}$, de 18 de julho de 2000. Regulamenta o art. 225, § $1^{\circ}$, incisos I, II, III e VII da Constituição Federal, institui o Sistema Nacional de Unidades de Conservação da Natureza e dá outras providências. Diário Oficial da República Federativa do Brasil, Brasília, 19 jul. 2000.

BRASIL. 2006. Decreto $s / n^{\circ}$, de 23 de março de 2006. Cria o Parque Nacional dos Campos Gerais, no Estado do Paraná, e dá outras providências. Diário Oficial da União, Brasília, 24 mar. 2006.

BRASIL. Ministério do Turismo. Ecoturismo: orientações básicas. Brasília: Ministério do Turismo, 2010.

BRILHA, J.. Património geológico e geoconservação: a conservação da natureza na sua vertente geológica. Braga: Palimage, 2005.

CARVALHO, I. C. M.. Educação ambiental: a formação do sujeito ecológico. 2 ed. São Paulo: Cortez, 2006.

DENCKER, A. F. M.. Métodos e técnicas de pesquisa em turismo. São Paulo: Futura, 1998.

FARIAS, E. K. V.. A construção de atrativos turísticos com a comunidade. In: MURTA, S. T.; ALBANO, C.. Interpretar o patrimônio: um exercício do olhar. Belo Horizonte: EdUFMG; Território Brasilis, 2002.

FÚSTER, L. F.. Introducción a la teoria y técnica del turismo. Madrid: Alianza Universidad Textos, 1991.

HORODYSKI, G. S.. O artesanato dos Campos Gerais do Paraná. Dissertação (Mestrado em Turismo e Hotelaria) - Universidade do Vale do Itajaí, Balneário Camboriú, 2006. 
ICMBio. Site oficial do Instituto Chico Mendes de Conservação da Biodiversidade. Disponível: <http://www.icmbio.gov.br/portal/>. Acesso: 09 out 2012.

LOUREIRO, C. F. B.. Trajetória e fundamentos da educação ambiental. 3 ed. São Paulo: Cortez, 2009.

MEIHY, J. C. S. B.. Manual de história oral. 5 ed. São Paulo: Loyola, 2005.

MELO, M. S.; LOPES, M. C.; BOSKA, M. A.. Furna do Buraco do Padre, Formação Furnas, PR -

Feições de erosão subterrânea em arenitos devonianos da Bacia do Paraná. In: SCHOBBENHAUS, C. et al.. Sítios geológicos e paleontológicos do Brasil. Brasília: CPRM, 2009.

MOESCH, M. M.. A produção do saber turístico. São Paulo: Contexto, 2002.

MOREIRA, J. C.. Geoturismo e interpretação ambiental. Ponta Grossa: UEPG, 2011.

MURTA, S. M.. Turismo histórico-cultural: parques temáticos, roteiros e atrações âncora. In: MURTA, S. M.; ALBANO, C.. Interpretar o patrimônio: um exercício do olhar. Belo Horizonte: EdUFMG; Território Brasilis, 2002.

Ponta Grossa. Cannyon e cachoeira do rio São Jorge. Disponível:

<http://www.pontagrossa.pr.gov.br/cannyon-e-cachoeira-do-rio-sao-jorge>. Acesso: 12 out 2012.

RODRIGUES, A. B.. Turismo e espaço: rumo a um conhecimento transdisciplinar. São Paulo: Hucitec, 1997.

RUSCHMANN, D. V. M.. Turismo e Planejamento Sustentável: a proteção do meio ambiente. Campinas: Papirus, 1997.

SANTOS, M.. Metamorfoses do espaço habitado. 5 ed. São Paulo: Hucitec, 1997.

SOIFER, J.. Empreender turismo e ecoturismo. Rio de Janeiro: Qualitymark, 2005.

STIGLIANO, B. V.. Participação comunitária e sustentabilidade socioambiental do turismo na vila ferroviária de Paranapiacaba, S.P. Tese (Doutorado em Ciência Ambiental) - Universidade de São Paulo, São Paulo, 2009.

TILDEN, F.. Interpreting our heritage. 3 ed. University of North Carolina Press, 1977.

TRIVIÑOS, A. N. S.. Introdução à pesquisa em ciências sociais: a pesquisa qualitativa em educação. São Paulo: Atlas, 1987.

UNWTO. International Recommendations for Tourism Statistics 2008. Disponível:

<http://media.unwto.org/en/content/understanding-tourism-basic-glossary>. Acesso: 13 ago 2012.

WESTERN, D.. Prefácio: definindo ecoturismo. In: LINDBERG, K.; HAWKINS, D. E.. Ecoturismo: um guia para planejamento e gestão. 3 ed. São Paulo: EdSenac São Paulo, 2001.

WWF. World Wild Found for Nature. Manual de ecoturismo de base comunitária: ferramentas para um planejamento responsável. Brasília: WWF, 2003. 